\title{
COMMERCIAL FOREST PLANTATION DEVELOPMENT POLICY: SOME MANAGEMENT STRATEGIES FOR IMPLEMENTATION
}

\author{
Mangala De Zoysa \\ Department of Agricultural Economics, University of Ruhuna, Mapalana
}

In the millennium, the transition of forestry reflecting profound social, economic and institutional changes is moving from the state dominant forest management to commercial enterprises, which are oriented towards production forestry. Many countries are undergoing dramatic shift in forest ownership pattern. Hence, the management strategies have to be changed from government managed forest to private forest plantation. The strategies should be revised, adapted, updated and communicated to private owners.

Sri Lanka at present, produce only 90 percent of the estimated wood consumption in the country. The demand is met by over exploiting the forest, which is not sustainable in the longrun. Therefore the forest policy and the forestry sector master plan in 1996 have emphasized the commercial forest plantation development to produce sufficient industrial and other woods by private sector management to cater the increasing demand. At the verge of implementing the new forest policy, it is vitally important to review the management strategies applicable to the changing environment.

The paper attempts to discuss the following strategies required to achieve successful commercial forest plantations. Boost the availability of suitable land; strengthen the commercial incentive environment and make plantations more profitable and less risky for private investors; Development of a plantation cultire among government, growers and the community; and improve information flows about plantation profitability and prospects. 